\title{
Seismic activity beneath the Nankai trough revealed by DONET ocean-bottom observations
}

\author{
Masaru Nakano • Takeshi Nakamura • \\ Shin-ichiro Kamiya $\cdot$ Yoshiyuki Kaneda
}

Received: 28 May 2013/ Accepted: 7 September 2013/Published online: 29 September 2013

(C) The Author(s) 2013. This article is published with open access at Springerlink.com

\begin{abstract}
We conducted a detailed investigation of seismic activity from January 2011 to February 2013 along the Nankai trough off the Kii Peninsula, central Japan, by using data obtained from the DONET ocean-bottom observation network. The hypocenters are mostly within the subducting Philippine Sea (PHS) plate, although a few are along the plate boundary or in the sedimentary wedge below the Kumano forearc basin. The seismic activity can be separated into events above and below $20 \mathrm{~km}$ depth, which corresponds approximately to the Moho. The hypocenter distributions are distinctly different for these groups. The seismic activity in the oceanic crust can be further separated into three clusters. Most of the seismic activity recorded in our data represents aftershocks of the 2004 off the Kii Peninsula earthquakes $\left(M_{\mathrm{JMA}}=7.1,7.4\right.$, and 6.5), which occurred in the PHS plate. The hypocenter distribution in the oceanic crust correlates well with the location of the Paleo-Zenisu ridge, which is formed by a chain of seamounts that is subducting beneath the forearc basin. The hypocenters in the uppermost mantle are aligned on a plane dipping to the southeast, consistent with the existence of a thrust fault cutting through the lithosphere of the oceanic plate. The focal mechanisms of the earthquakes show that the axis of compressive stress in the PHS plate is oriented $\mathrm{N}-\mathrm{S}$, almost perpendicular to the direction of plate convergence, indicating a complex tectonic regime in this region. These results suggest that intraplate shortening may be occurring in the subducting oceanic plate.
\end{abstract}

M. Nakano $(\varangle) \cdot$ T. Nakamura · S. Kamiya · Y. Kaneda Earthquake and Tsunami Research Project for Disaster Prevention, Japan Agency for Marine-Earth Science and Technology (JAMSTEC), 3173-25 Showa-machi, Kanazawa-ku, Yokohama, Kanagawa 236-0001, Japan

e-mail: mnakano@jamstec.go.jp
Keywords Hypocenter distribution . Paleo-Zenisu ridge · Ocean-bottom seismometers . 2004 off the Kii Peninsula earthquakes

\section{Introduction}

Along the Nankai trough off southwestern Japan, the Philippine Sea (PHS) plate is subducting to the northwest below the Eurasian plate at a convergence rate of about $65 \mathrm{~mm} /$ year (e.g., Kreemer et al. 2003). Historically, mega-thrust earthquakes have occurred repeatedly along the Nankai trough (e.g., Ando 1975). Future great earthquakes will cause serious and widespread damage in central and western Japan. The Japan Agency for Marine-Earth Science and Technology (JAMSTEC) installed a network of permanent ocean-bottom observation stations off the Kii Peninsula above the source region of the expected great earthquakes. This is known as the Dense Oceanfloor Network System for Earthquakes and Tsunamis (DONET; Fig. 1). One of the primary objectives of DONET is early detection of earthquakes and tsunamis in this region. DONET stations now cover the source region of the 1944 Tonankai earthquake. In the next stage of development the observation network will be extended to the west along the Nankai trough to cover the source region of the 1946 Nankai earthquake. Another objective of DONET is to use monitoring data in detailed studies of the tectonic framework of this region.

The most recent significant seismic activity in this region was the sequence of 2004 off the Kii Peninsula earthquakes $\left(M_{\mathrm{JMA}}=7.1,7.4\right.$, and 6.5). These earthquakes occurred below the trough axis and were intraplate earthquakes within the oceanic crust of the subducting PHS 
Fig. 1 Regional location map (inset) and distribution of DONET ocean-bottom seismic stations off the Kii Peninsula. Gray triangles and linking black lines indicate locations of DONET stations and the fiber optic cables connecting them. Gray lines are bathymetric contours. Black line indicates the estimated location of the Nankai trough axis thrust fault with teeth on the upthrown side. Gray arrows indicate the motion of the Philippine Sea plate with respect to the Eurasian plate, based on the GSRM v. 1.2 plate motion model. Stars indicate source locations of the CMT solutions from NIED F-net data for the foreshock, mainshock, and largest aftershock of the 2004 events; their focal mechanisms are also shown. Dashed rectangle encloses the area shown in Figs. 2, 4, and 5

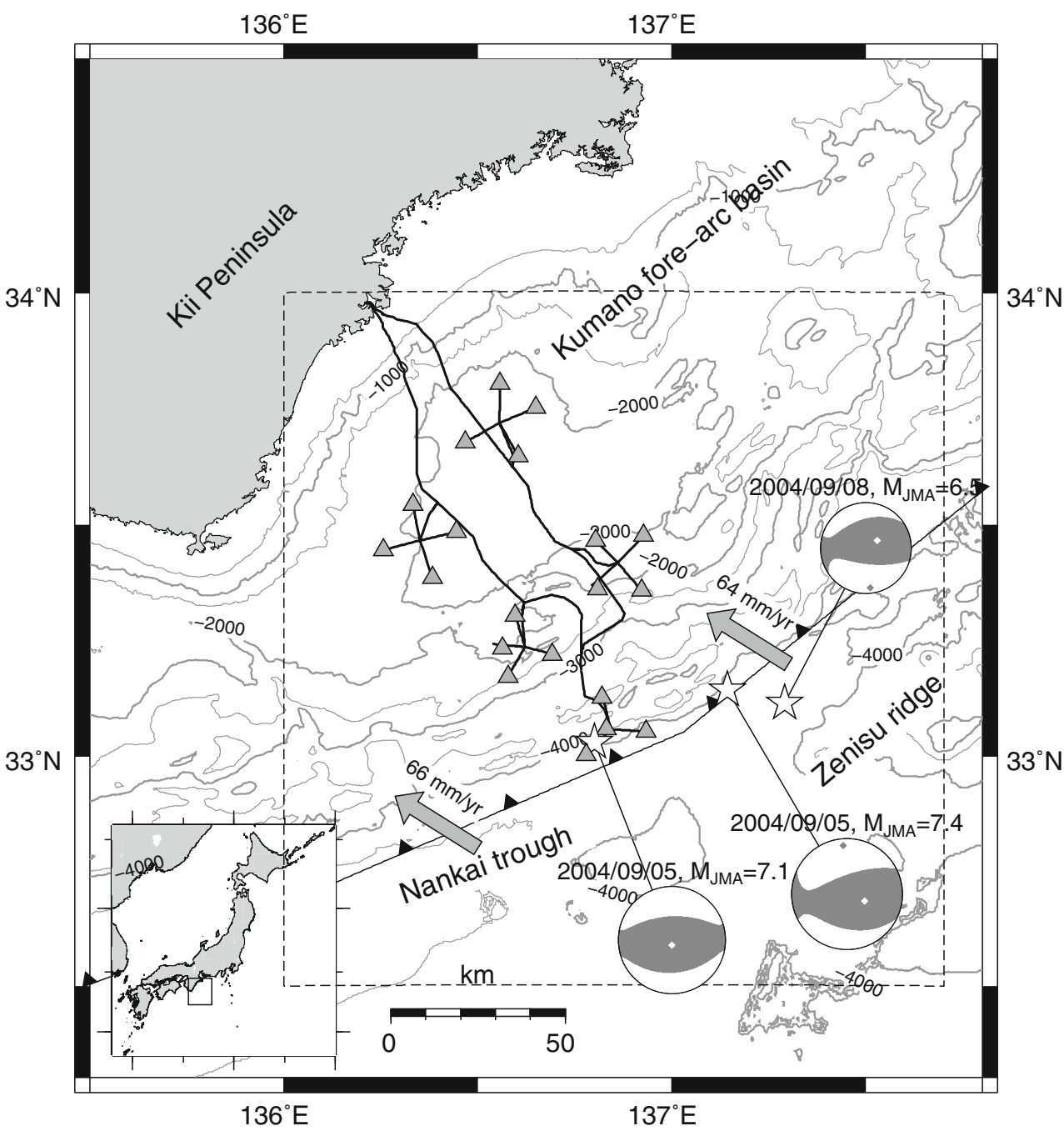

plate (Fig. 1). Although the centroid moment tensor (CMT) solutions for these earthquakes obtained by F-net operated by the National Research Institute for Earthquake Prediction and Disaster Prevention (NIED) show a focal mechanism with $\mathrm{P}$ axis trending $\mathrm{N}-\mathrm{S}$ (see Fig. 1), details of the rupture process of the mainshock are controversial. Some researchers consider that this event was a composite of movements on both a dip-slip fault below the trough axis and a strike-slip fault below the Kumano forearc basin (e.g., Yagi 2004; Satake et al. 2005; Hara 2005). Other researchers have proposed a model in which the mainshock ruptured a reverse fault below the forearc basin (e.g., Yamanaka 2004; Baba et al. 2005; Matsumoto and Mikada. 2005; Saito et al. 2010). After the 2004 earthquakes, verylow-frequency (VLF) earthquake activity was triggered above the source region (Obara and Ito 2005). Recent studies show that the VLF earthquakes are in the sedimentary wedge or at the plate boundary (Ito and Obara 2006; Sugioka et al. 2012). Kitajima and Saffer (2012) considered that elevated pore pressures in the sediments play an important role in the generation of VLF earthquakes.

The Zenisu ridge, formed by a chain of seamounts rising $2,000 \mathrm{~m}$ from the bottom of the Nankai trough, lies southeast of the DONET stations (Fig. 1). The ridge runs almost parallel to the trough axis and a thrust cutting through the lithosphere of the PHS plate is found below this ridge (e.g., Lallemant et al. 1989; Nakanishi et al. 1998, 2002b; Mazzotti et al. 2002). The slip on the thrust below this ridge may indicate shortening of the oceanic plate in this region (e.g., Mazzotti et al. 2002). Northwest of this ridge, seafloor morphologic data (Lallemand et al. 1992; Okino and Kato 1995) and geomagnetic data (Le Pichon et al. 1996) show a structure below the Kumano forearc basin that represents a subducting seamount. This seamount is part of the Paleo-Zenisu ridge, which was also formed by a chain of seamounts that is almost parallel to the trough axis, $20-30 \mathrm{~km}$ wide, about $200 \mathrm{~km}$ long, and 
with a maximum height of $2.5 \mathrm{~km}$. Park et al. (2003) made a detailed estimate of the extent of the Paleo-Zenisu ridge from seismic reflection and refraction data and showed that it correlates well with the seaward edge of the coseismic rupture zone of the 1944 Tonankai earthquake $\left(\mathrm{M}_{\mathrm{w}}=8.1\right)$. They considered that the ridge affects mechanical coupling at the plate boundary.

In a previous study (Nakano et al. 2013), based on data from January to August 2011, we showed that DONET ocean-floor observation data provide a better detection capability and higher precision of earthquake source locations below the Nankai trough than analyses based only on onshore observation data. However, DONET was still under construction during most of the analysis period; construction of the final planned station was finished in the end of June 2011. Accordingly, the detection capability and resolution of earthquake source location was still limited, especially south of the observation network. In this study, we extended our analysis period to cover the period from January 2011 to February 2013. Adding 1.5 years data from full-operation network, we have developed more comprehensive earthquake catalogue off the Kii peninsula. The hypocenters correlate well with the aftershock distribution of the 2004 earthquakes. We also used the new data to investigate earthquake focal mechanisms. This new and larger dataset forms the basis of our discussion of the tectonic implications of seismic activity along the Nankai trough.

\section{Data and analysis method}

DONET is a cabled ocean-bottom observation network system consisting of 20 permanent stations installed on the ocean floor of the Kumano forearc basin (Fig. 1). Seismic signals are recorded by a broadband seismometer (Guralp CMG-3T) and a strong-motion seismometer (Metrozet TSA-100S) at each station. The seismometers are buried $1 \mathrm{~m}$ below the ocean floor to minimize environmental noise. The signals from the seismometers are sampled at $200 \mathrm{~Hz}$ per channel by a 24-bit analog to digital converter on site and then transferred in real time by fiber optic cable to our laboratory.

For hypocenter determinations we used data obtained from DONET stations, from land stations on the Kii Peninsula operated by the Japan Meteorological Agency (JMA), and from Hi-net and F-net stations operated by NIED. We followed the analysis method of Nakano et al. (2013), which is summarized below.

First, P- and S-wave first arrivals at each station were picked manually. Initial hypocenters were determined by the method of Hirata and Matsu'ura (1987). We assumed the layered P-wave velocity structure compiled for this region by Nakamura et al. (2011). The S-wave velocity (Vs) was calculated assuming a $\mathrm{Vp} / \mathrm{Vs}$ ratio of 1.8 , where
$\mathrm{Vp}$ is P-wave velocity. We determined the hypocenters for earthquakes for which we had at least six $\mathrm{P}$ and/or $\mathrm{S}$ readings. The local magnitude $\left(\mathrm{M}_{\mathrm{L}}\right)$ was determined from the maximum amplitude of the vertical velocity seismograms (Watanabe 1971). We incorporated station corrections for P- and S-wave arrival times, which were obtained from the averaged differences between observed and calculated travel times. The error of the initial hypocenter location depends on where the earthquake occurs. The averaged error in each earthquake cluster (see Fig. 4) is as follows: In cluster $\mathrm{A}$, the error is less than $1 \mathrm{~km}$ in both horizontal and vertical directions. In cluster $\mathrm{B}$, the error is 1-2 and $6 \mathrm{~km}$ in horizontal and vertical directions, respectively. In cluster $\mathrm{C}$ and events deeper than $20 \mathrm{~km}$, the error is 1 and $2 \mathrm{~km}$ in horizontal and vertical directions, respectively.

After initial determination of hypocenters, we obtained a detailed hypocenter distribution by using the double-difference (DD) method (Waldhauser and Ellsworth 2000). The DD method minimizes errors due to structures not resolved by velocity modeling and improves the precision of relative source locations in a seismic activity swarm. Because the DD method assumes that the recording stations are at sea level, we reduced the source depths of the initial hypocenters by $2 \mathrm{~km}$, which corresponds to the average seafloor depth of the Kumano forearc basin; most of the DONET stations are at about this depth (Fig. 1). The source depths were increased by $2 \mathrm{~km}$ after application of the DD method. We used arrival time differences for 165,841 and 233,255 pairs of $P$ and $S$ waves, respectively. Selecting neighboring events within $5 \mathrm{~km}$, we relocated 5,041 events. After relocation, the RMS of the DD time residual was reduced from 423 to $109 \mathrm{~ms}$. We removed some scattered earthquakes that were not well grouped with other events in the obtained hypocenter distribution. We note that for the DD method, the absolute location of earthquake clusters depends on the initial hypocenter distribution. Because the initial hypocenter locations depend on the assumed velocity model, we repeated our analysis using different $\mathrm{Vp} / \mathrm{Vs}$ ratios. Although the obtained source depths were dependent on the assumed $\mathrm{Vp} / \mathrm{Vs}$ ratio, it had little effect on the epicenter distribution.

We also determined earthquake focal mechanisms by the method of Imanishi et al. (2006a, b, c). In this method, the $\omega^{2}$-model (Boatwright 1978) is fitted to the amplitude spectrum of the direct $\mathrm{P}$ or $\mathrm{S}$ waves at each station, and the level extrapolated to DC is used as its amplitude. Assuming a double-couple source, the obtained amplitude distribution is inverted to obtain the focal mechanism. In this study we used $\mathrm{P}$-wave amplitude and polarity. If the $\mathrm{P}$-wave polarity was not clear, the absolute value of amplitude was used. $\mathrm{S}$-waves were not used because their amplitudes can be strongly affected by amplification in the sedimentary layers 
below the station. Using the P-wave amplitude and polarity distribution, the obtained mechanism is less ambiguous than that traditionally obtained by the P-wave polarity distribution, even when station coverage of the source is not good. We applied the inversion to events with $\mathrm{M}_{\mathrm{L}}>3$. After checking the stability of the results, we obtained focal mechanisms for 24 events. Magnitudes recalculated from the seismic moment obtained by the inversion were between 2.8 and 3.7. The stability of the focal mechanism determination is shown in Appendix.

\section{Results}

We obtained hypocenters of more than 5,000 earthquakes (Fig. 2), more than five times the number determined in our previous study (Nakano et al. 2013). The seismic activity occurred mainly below the Nankai trough and Kumano forearc basin and extended over distances of about $100 \mathrm{~km}$ in both the $\mathrm{N}-\mathrm{S}$ and $\mathrm{E}-\mathrm{W}$ directions. Most of the earthquakes were at depths between 5 and $40 \mathrm{~km}$. The hypocenter distribution correlates well with that of the aftershocks immediately after the 2004 earthquakes (e.g., Sakai et al. 2005). The seismically active region shown by our new data is different from that before the 2004 earthquakes. Before the events, earthquakes occurred in several clusters located southwest of the activity obtained in this study (Obana et al. 2004, 2005). Although the overall distribution is similar to that obtained in our previous study (Nakano et al. 2013), the new dataset improved our capability to detect earthquakes, especially south of the observation network, and we have recognized several new features described below.

The seismic activity is clearly separated according to depth into two groups (Fig. 3). The shallower events are mainly within the oceanic crust of the PHS plate, but extend several kilometers into the uppermost mantle in some places (Fig. 3). The deeper events are in the uppermost mantle, and include events of higher magnitude than the shallow group. There is a clear gap in the hypocenter distribution at about $20 \mathrm{~km}$ depth (note that this depth is dependent on the assumed velocity model), which approximates the depth to the Moho. The distributions of the hypocenters of events above and below this gap (Fig. 4) are clearly different. Hereafter, we refer to the shallower and deeper events as those in oceanic crust and uppermost mantle, respectively, although the shallower events extend into the uppermost mantle in some places.

The seismic activity in the oceanic crust (Fig. 4a) can be separated into three clusters. The activity in the north (cluster A in Fig. 4a) corresponds well with the aftershock distribution of the 2004 events (Sakai et al. 2005), which showed a NW-SE trend. The distribution of cluster A hypocenters in our new data is narrower than the active region immediately after the 2004 mainshock. In addition to the overall NW-SE trend within cluster A, there is an ENE-WSW trend, almost parallel to the trough axis. This trend was not so clear in our previous study. Cross sections along these trends show that the hypocenters are at depths between 5 and $20 \mathrm{~km}$ (Fig. 3a, c).

Another cluster of seismic activity to the southeast of cluster A (cluster B in Fig. 4a) shows a clear NE-SW trend, which activity was not clearly recognized in our previous study. This may be due to weak detection capability in this region. The F-net CMT solution of the mainshock of the 2004 events is in this region (Fig. 1). Aftershocks immediately after the 2004 mainshock were widely distributed in this region (Sakai et al. 2005), whereas our data show activity to be limited to a narrower region.

In cluster C (west of cluster B, Fig. 4a), the hypocenters are distributed in a narrow region with a $\mathrm{N}-\mathrm{S}$ trend in the northern part of the cluster, but we found a more scattered $\mathrm{E}-\mathrm{W}$ trend south of the trough axis. Some hypocenters are within the sedimentary wedge at the northern end of cluster C (Fig. 3b, d). This cluster lies outside the 2004 aftershock region; Nakano et al. (2013) attributed this cluster to activity along pre-existing weak structures in the incoming PHS plate. We note that there are some ambiguities in the source depths of earthquakes in clusters B and C, which may reflect the assumed velocity structure.

Most of the $\mathrm{M}_{\mathrm{L}}>3$ earthquakes in the oceanic crust show strike-slip focal mechanisms with the $\mathrm{P}$ axis trending NNE-SSW (Fig. 5). This mechanism is very similar to that obtained by Obana et al. (2005) for earthquakes close to cluster $\mathrm{C}$. Since one of the nodal planes corresponds to the earthquake alignment in cluster C, Obana et al. (2005) attributed these events to activity on a fault that was formed in the oceanic crust before subduction took place.

The hypocenter distribution in the upper mantle (Fig. 4b) is simpler than that in the oceanic crust, with most hypocenters lying in a region below and between clusters $\mathrm{B}$ and $\mathrm{C}$, and elongate parallel to the trough axis. Source depths are deeper in the southwest, implying activity on a plane dipping to the southwest, although the dip angle is dependent on the assumed velocity structure. Although the largest shocks of the 2004 earthquakes were in the oceanic crust, aftershocks immediately after the mainshock extended to the uppermost mantle (Sakai et al. 2005). The seismic activity shown by our data corresponds well with the 2004 aftershock distribution and may be indicative of ongoing aftershock activity. The focal mechanisms of earthquakes in the uppermost mantle are dominated by reverse faults with NNE-SSW P axes (Fig. 5). The mechanisms obtained for earthquakes in the northeast (within the blue circle in Fig. 5) show some variation, so we used the triangular classification system of Frohlich $(1992,2001)$, which shows most of them to have a 


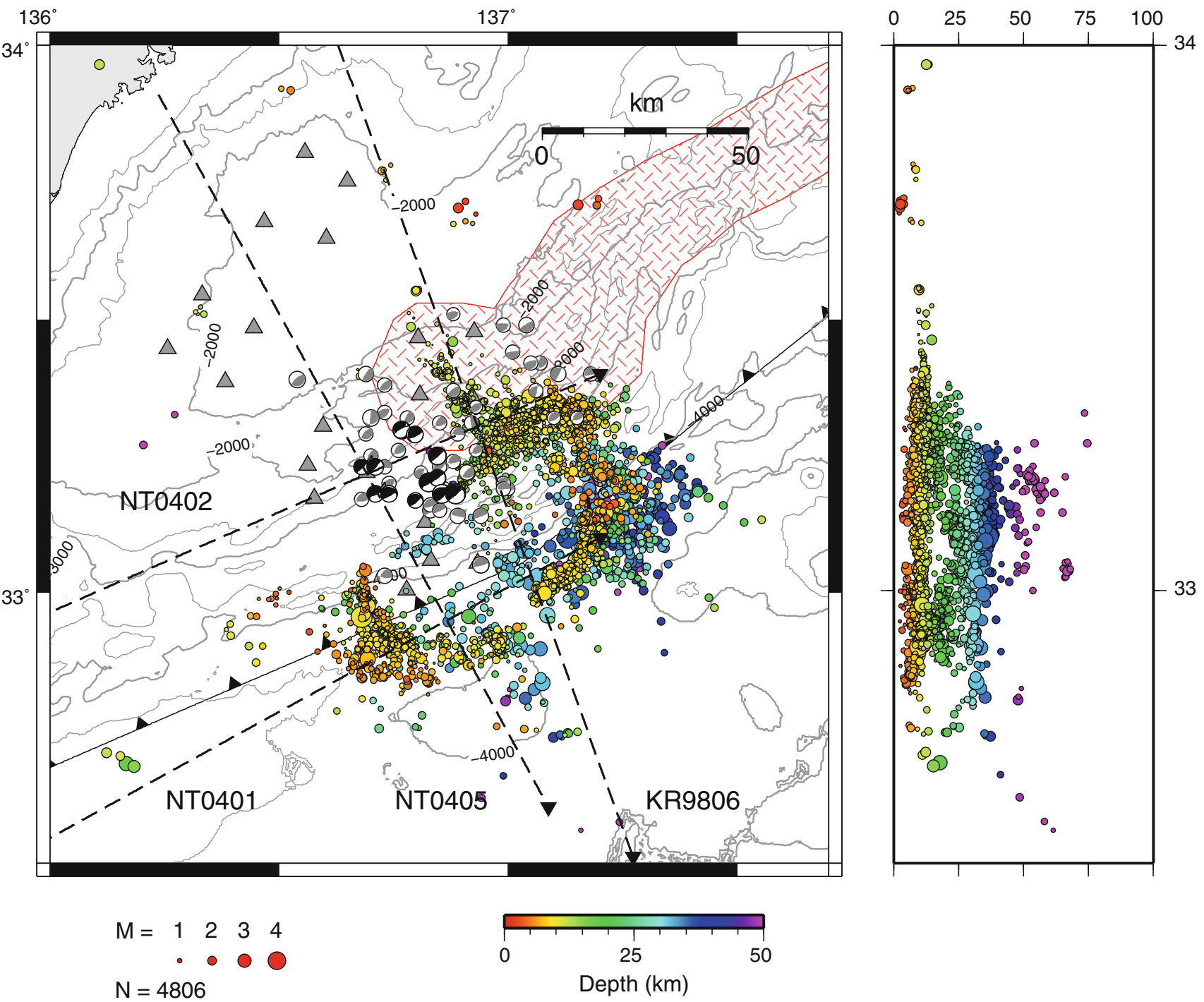

Fig. 2 Distribution of earthquake hypocenters (circles) relocated by the double-difference method (Waldhauser and Ellsworth 2000). The color and size of circles represent source depth and earthquake magnitude, respectively. Black focal mechanisms are CMT solutions of VLF earthquakes of Sugioka et al. (2012); gray focal mechanisms

reverse fault mechanism (Fig. 6). The trend of the P axes of these events is similar to those of both the southwestern activity in the uppermost mantle and the activity in the oceanic crust.

We found only limited seismic activity along the plate boundary, and very little in the region corresponding to the large slip of the 1944 Tonankai earthquake determined by Kikuchi et al. (2003) (Fig. 3a). We also found only a few earthquakes in the sedimentary wedge. Although very-lowfrequency (VLF) earthquakes are known to occur in the sedimentary wedge and at the plate boundary in this region (Obara and Ito 2005; Ito and Obara 2006; Sugioka et al. 2012), their distribution has little overlap with that of the ordinary are those of Ito and Obara (2006). Dashed lines show the locations of seismic survey lines KR9806, NT0401, NT0402, and NT0405. Red hatched area shows the area of the Paleo-Zenisu ridge estimated by Park et al. (2003)

earthquakes (Fig. 2). The lack of ordinary earthquakes may reflect a sedimentary wedge consisting of soft sediments in which insufficient stress can accumulate to nucleate earthquakes that radiate high-frequency seismic waves. However, the earthquakes we detected in the sedimentary wedge do not show characteristics of VLF earthquakes.

\section{Discussion}

Most of the seismic activity in our data from around the Nankai trough corresponds well with the aftershock distribution of the 2004 off the Kii Peninsula earthquakes, 
Fig. 3 Hypocenter distributions superimposed on vertical sections of seismic structure along survey lines a KR9806 (Nakanishi et al. 2002a), b NT0405 (Nakanishi et al. 2008), c NT0402 (Kodaira et al. 2006), and d NT0401 (Kodaira et al. 2006). Horizontal axis indicates distance along the survey line measured from the inverted triangle shown in Fig. 2. The $8 \mathrm{~km} / \mathrm{s} \mathrm{P}$-wave velocity contour approximately correspond to the Moho. Coseismic rupture zone of the 1944 Tonankai earthquake (Kikuchi et al. 2003) is shown at the top of (a)
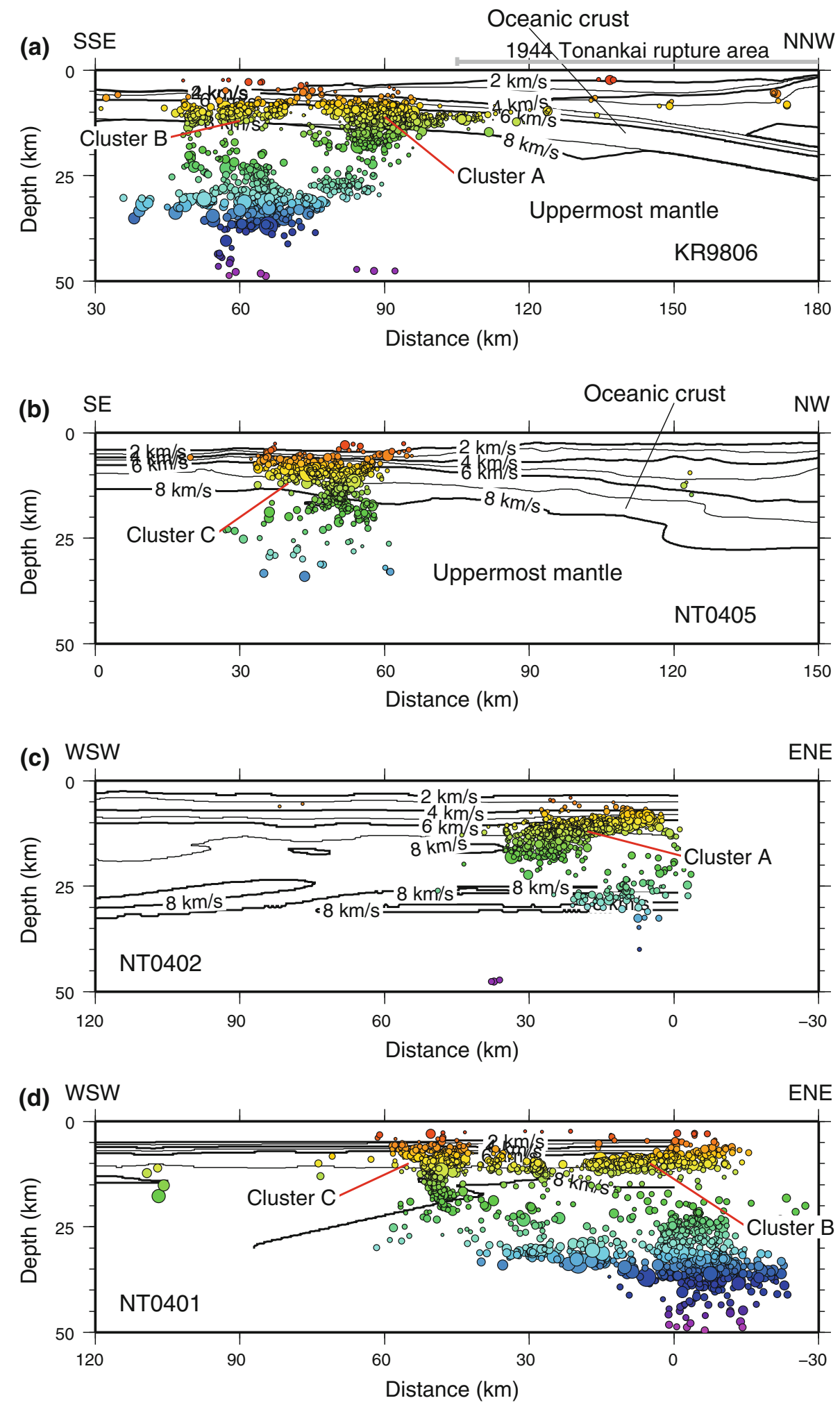

indicating that they represent continuing aftershock activity. The CMT solutions of the 2004 events show that the sources of the foreshock, mainshock, and largest aftershock were below the trough axis (Fig. 1) at depths between 5 and $15 \mathrm{~km}$. The mainshock caused tsunamis of up to $0.9 \mathrm{~m}$ height along the coast of the Kii Peninsula (e.g., Satake et al. 2005; Baba et al. 2005; Matsumoto and Mikada 2005), which suggests that the 2004 events occurred in oceanic crust, although aftershock activity has extended to the uppermost mantle (Sakai et al. 2005). The CMT 


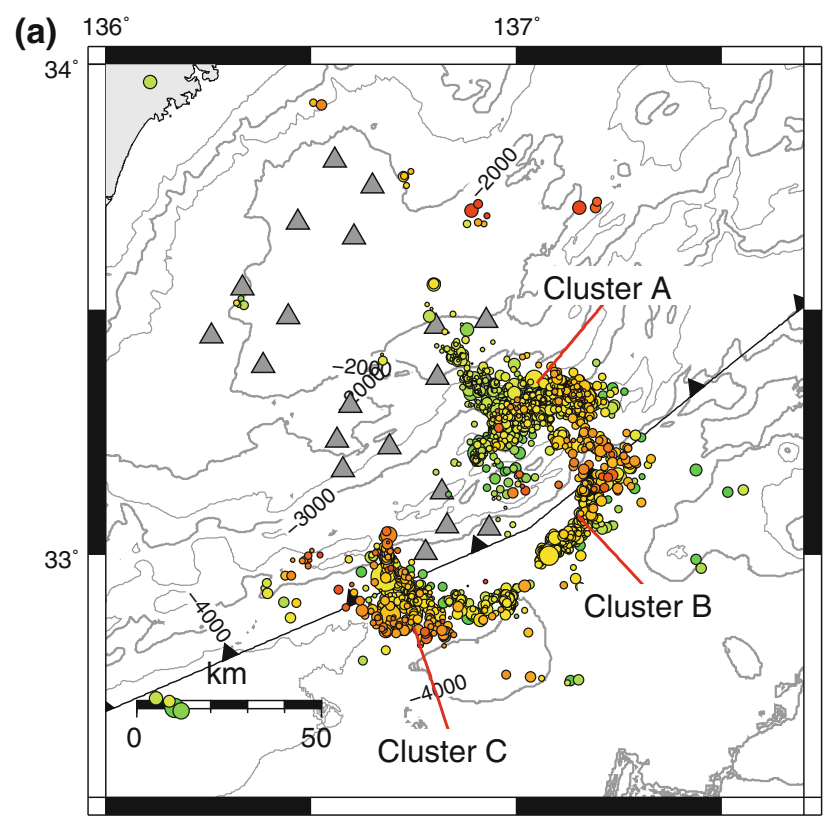

(b)

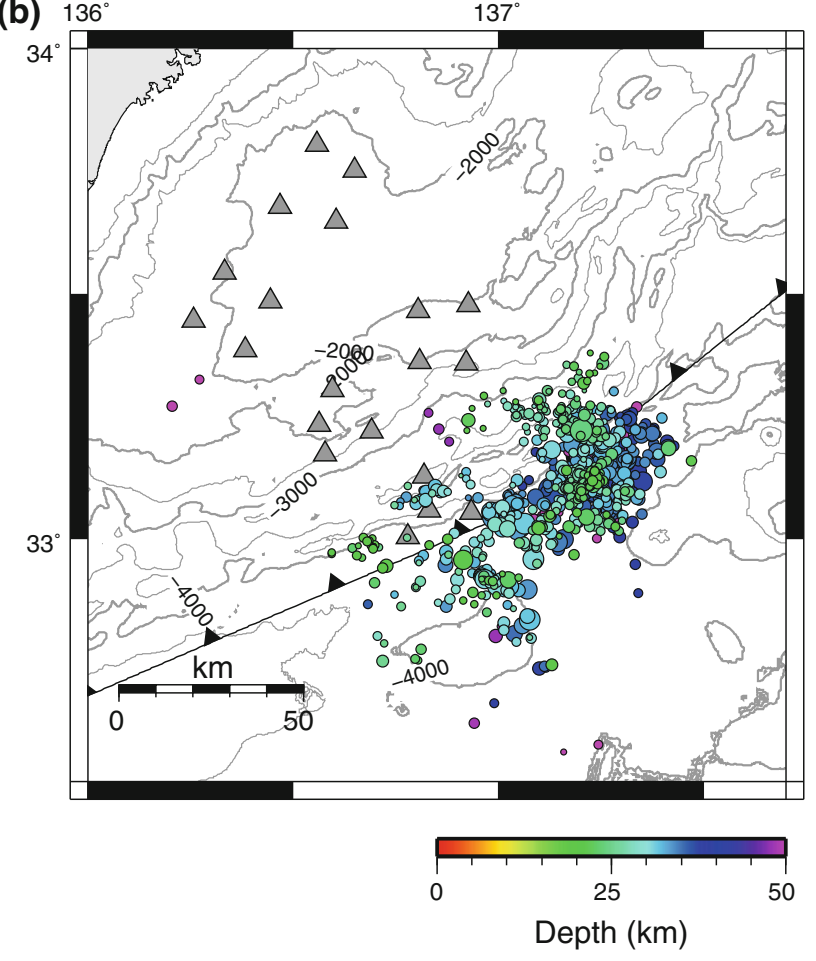

Fig. 4 Earthquake hypocenters a shallower than $20 \mathrm{~km}$ and $\mathbf{b}$ deeper than $20 \mathrm{~km}$

solutions show significant non-double-couple components (about 15-20\%), implying complex rupture processes.

Many source models have been proposed for the mainshock of the 2004 events, and the subject remains controversial. One group proposes that the mainshock is the composite result of dip-slip on a fault below the trough axis, consistent with the CMT solution, and a strike-slip fault of NW-SE strike below the Kumano forearc basin, corresponding to the activity of cluster A (e.g., Yagi 2004; Satake et al. 2005; Hara 2005). Another group proposes that the mainshock occurred on a NW-SE striking reverse fault extending between the trough axis and the forearc basin and dipping to the southwest. This model is based on the aftershock distribution corresponding to cluster A and the initial seawater uplift estimated from tsunami observations (e.g., Yamanaka 2004; Baba et al. 2005; Matsumoto and Mikada 2005; Saito et al. 2010), although the reverse fault of this model is in conflict with the CMT solution.

The earthquakes in cluster $\mathrm{A}$ are distributed in an area extending over several tens of kilometers. This cluster corresponds well with the aftershock distribution, but we could not recognize a planar structure within the hypocenter distribution. Thus, it is difficult to identify a fault model for the 2004 mainshock. The distribution of the earthquakes below the trough axis (cluster B) has a NE$\mathrm{SW}$ orientation, which is consistent with the strike of one of the nodal planes of the CMT solution, although no planar structures were evident in this distribution.

The earthquakes in the subducting plate can clearly be separated into those in the oceanic crust and those in the uppermost mantle (e.g., Fig. 3a). A schematic view of the earthquake distributions (Fig. 7a) shows that the earthquakes in the uppermost mantle are associated with a southeast-dipping plane extending about $50 \mathrm{~km}$ along dip (see Fig. 4), implying the existence of a thrust in the lithosphere of the PHS plate. Above this planar distribution, activity in the mantle is scattered without a recognizable trend. There are clusters of activity in the oceanic crust above the middle and the northwestern end of the planar distribution of activity in the uppermost mantle; these correspond to clusters B and A, respectively.

The Zenisu ridge lies southeast of the study area (Fig. 1). Below this bathymetric high a thrust is found in the lithosphere of the PHS plate (e.g., Lallemant et al. 1989; Nakanishi et al. 1998, 2002b; Mazzotti et al. 2002). Northwest of this ridge, the Paleo-Zenisu ridge is a similar bathymetric high formed on the PHS plate, which is also subducting beneath the Kumano forearc basin (Fig. 2). The formation of these ridges was a result of intraplate shortening in the subducting plate (Mazzotti et al. 2002). Park et al. (2003) showed that the southwestern edge of the Paleo-Zenisu ridge corresponds well with the area of dense earthquake activity in cluster A (Fig. 2).

To attempt to explain the earthquake distribution around the Zenisu ridge, Mazzotti et al. (2002) computed the changes in Coulomb failure stress (CFS) in the oceanic crust that would be caused by slip on a thrust in the uppermost mantle. They found two areas of CFS increase in the oceanic crust for a thrust (Fig. 7b), one at the upward 


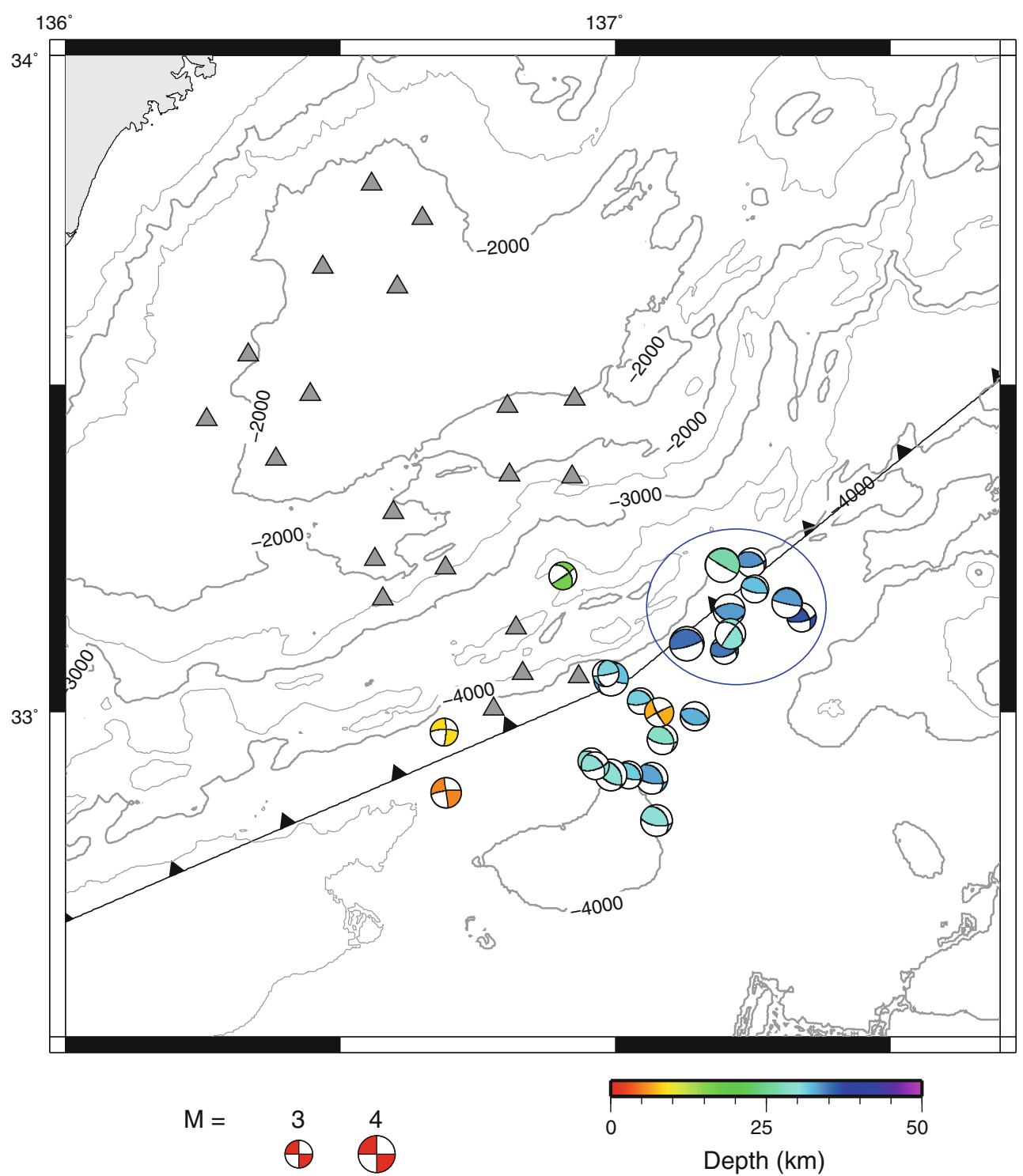

Fig. 5 Focal mechanisms of earthquakes with local magnitude $\left(\mathrm{M}_{\mathrm{L}}\right)$ greater than 3 . The color and size of the symbols represent source depth and earthquake magnitude, respectively. See Fig. 6 for classification of mechanisms of earthquakes enclosed by the blue circle

extension of the thrust and the other on the upthrown side of the thrust, similar to clusters A and B of this study (Fig. 7a). Therefore, if we assume a thrust in the uppermost mantle below the Nankai trough, the spatial distribution of the seismic activity of our data corresponds well with the resultant increase of CFS in the oceanic crust.

Despite the similarity of the spatial patterns of the seismically active regions shown in Fig. 7a, b, the thrust below the Nankai trough assumed in this study dips southeast (Fig. 7a), whereas the thrust below the Zenisu ridge of previous studies (e.g., Nakanishi et al. 1998, 2002b; Mazzotti et al. 2002) dips northwest. In mechanical terms, these thrusts are not contradictory; both reflect compressive stress within the PHS plate. However, the position of the PaleoZenisu ridge on the surface of the PHS plate does not correspond to the area that would be uplifted by slip on the assumed thrust below the Nankai trough (Fig. 7a), so thrusting may not be the primary factor in formation of the ridge. The focal mechanisms of the earthquakes in the mantle are reverse faults, but neither of the two nodal planes matches the dip of the assumed thrust (Fig. 5). Therefore, we consider that the seismic activity of our data set reflects compressional deformation in the uppermost mantle, possibly indicating that intraplate shortening of the PHS plate is occurring below the Nankai trough. However, our data set does not allow us to clarify the fault structure.

The focal mechanisms obtained in this study show that the $\mathrm{P}$ axis is oriented NNE-SSW. The P axis of the CMT solutions obtained for the 2004 earthquakes (Fig. 1) and aftershocks (Ito et al. 2005) are of similar orientation. 
Fig. 6 Triangular classification system for earthquake mechanisms (Frohlich 1992) in the uppermost mantle below the axis of the Nankai trough (enclosed by blue circle in Fig. 5)

(a)

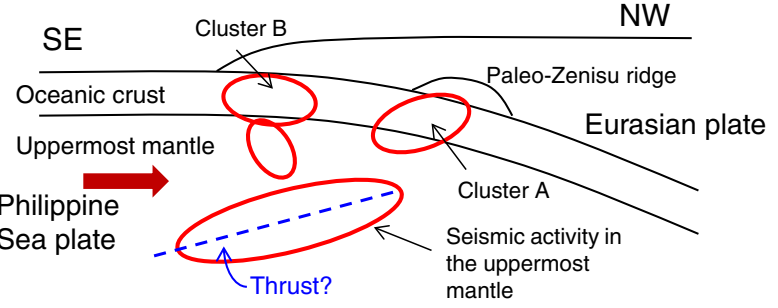

(b)

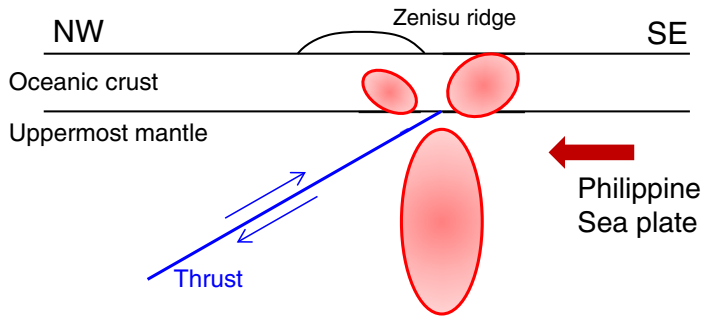

Fig. 7 Schematic diagrams a showing the seismically active region below the Nankai trough. Red circles indicate earthquake clusters. Blue dashed line indicates the thrust inferred from earthquake distributions. Thick red arrow indicates direction of motion of the Philippine Sea plate. b Areas of Coulomb stress increase (red-filled circles) due to slip on a thrust in the uppermost mantle (after Mazzotti et al. 2002). Blue line indicates the thrust. Thick red arrow indicates the direction of motion of the Philippine Sea plate assumed in the model of Mazzotti et al. (2002)
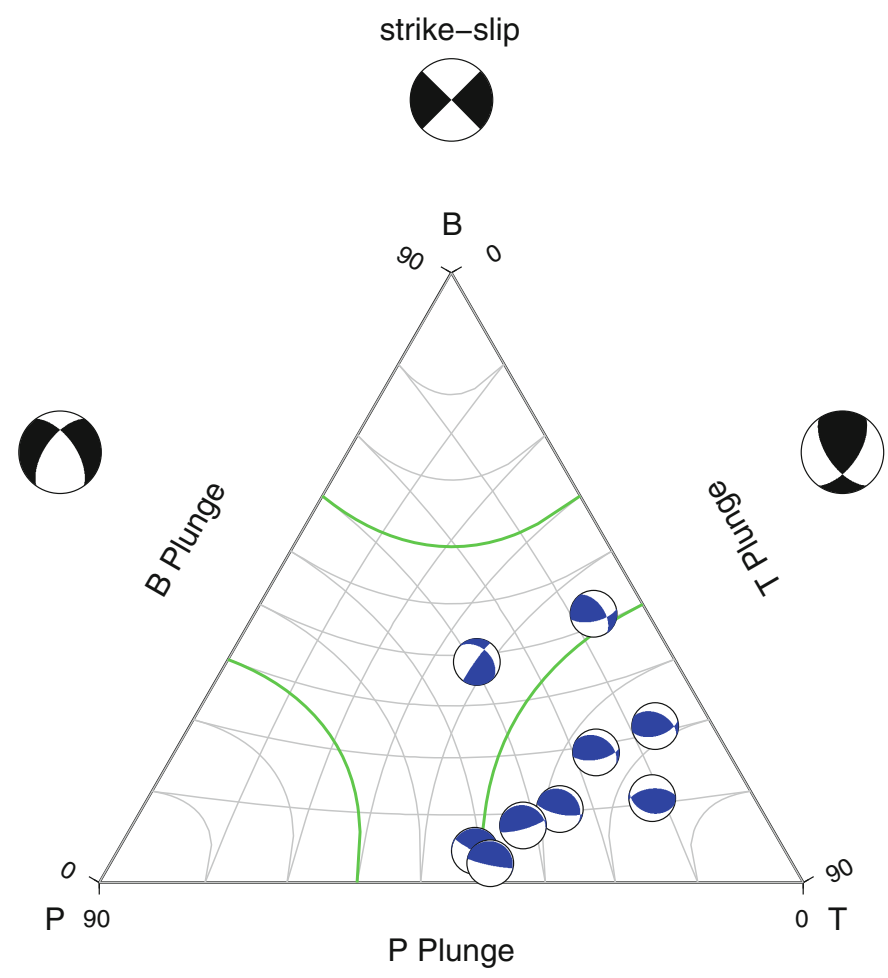

P Plunge
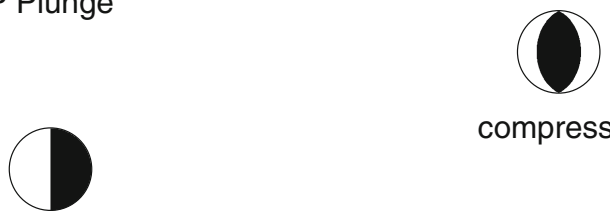

compression
Similar focal mechanisms have also been obtained for earthquakes before the 2004 events (e.g., Obana et al. 2004, 2005). These results suggest that the axis of compressive stress in the PHS plate is oriented N-S to NNE-SSW, almost perpendicular to the direction of motion of the PHS plate with respect to the Eurasian plate (see Fig. 1).

West of the Kii peninsula, Mochizuki et al. (2010) showed that the P-axis of intraslab earthquakes is oriented almost normal to the trough axis. This feature may be expected in a region where interplate coupling is strong. Yoshioka and Matsuoka (2013) showed strong intrerplate coupling ratio along the Nankai trough below the Kii peninsula. Accordingly, we would have expected a similar stress field in the PHS plate below southeast of the Kii peninsula, too. Bending of the plate due to subduction may also affect the stress field within the PHS plate (e.g., Seno 2005; Miyoshi and Ishibashi, 2005), in which compressional and tensional stress perpendicular to the trough axis dominate in the lower and upper parts, respectively, within the lithosphere. However, these mechanisms could not explain the observed direction of compressive stress oriented perpendicular to the direction of plate convergence. The focal mechanisms of the VLF earthquakes are mostly thrusts striking parallel to the trough axis (Fig. 2), which is 
Fig. 8 First column shows the earthquake source parameters. Second column shows the $\mathrm{P}$ wave amplitude and polarity distribution plotted on the focal sphere, superimposed on the best-fitting focal mechanism. Triangles and inverted triangles indicate upward and downward $P$ first motion, respectively. Squares indicate that $\mathrm{P}$ polarity is not clear, and absolute value of $\mathrm{P}$ wave amplitude is used for the inversion. Blue and red marks indicate observed and synthetic amplitudes, respectively. Size of the symbols is proportional to the amplitude, normalized by the maximum observed value. Third and fourth columns show the residual distribution with respect to the directions of $\mathrm{P}$ and $\mathrm{T}$ - axes, respectively, plotted on the focal sphere. The color scale is given in the fifth column. Blue and red circles indicate best-fitting directions of $\mathrm{P}$ - and T- axes, respectively

\section{1/07/07}

137.1 E, 33.2 N, dep 22 km

$\mathrm{M}_{\mathrm{L}}=3.8$, Res. $=0.09$

\section{$2011 / 08 / 03$}

137.1 E, 33.0 N, dep $10 \mathrm{~km}$ $\mathrm{M}_{\mathrm{L}}=3.3$, Res. $=0.03$

\section{1/09/07}

136.7 E, $32.9 \mathrm{~N}$, dep $9 \mathrm{~km}$ $M_{L}=3.6$, Res. $=0.06$

\section{1/09/08}

137.2 E, $33.1 \mathrm{~N}$, dep $33 \mathrm{~km}$ $M_{L}=3.3$, Res. $=0.08$

\section{1/09/14}

137.2 E, $33.2 \mathrm{~N}$, dep $33 \mathrm{~km}$ $M_{L}=4.1$, Res. $=0.14$

\section{$2011 / 10 / 29$}

137.2 E, $33.2 \mathrm{~N}$, dep $34 \mathrm{~km}$ $\mathrm{M}_{\mathrm{L}}=3.3$, Res. $=0.09$

\section{$2011 / 11 / 15$}

$137.0 \mathrm{E}, 32.9 \mathrm{~N}$, dep $29 \mathrm{~km}$ $\mathrm{M}_{\mathrm{L}}=3.2$, Res. $=0.10$

\section{$2011 / 11 / 28$}

137.1 E, 33.0 N, dep 32 km $M_{L}=3.0$, Res. $=0.07$

\section{$2011 / 12 / 04$}

$136.9 \mathrm{E}, 33.2 \mathrm{~N}$, dep $27 \mathrm{~km}$ $M_{L}=3.3$, Res. $=0.08$

2011/12/27

137.0 E, 33.1 N, dep $32 \mathrm{~km}$ $M_{L}=4.5$, Res. $=0.10$

\section{$2012 / 01 / 25$}

137.0 E, $32.9 \mathrm{~N}$, dep $32 \mathrm{~km}$ $\mathrm{M}_{\mathrm{L}}=3.3$, Res. $=0.14$

\section{2/03/08}

137.2 E, $33.2 \mathrm{~N}$, dep $32 \mathrm{~km}$ $\mathrm{M}_{\mathrm{L}}=3.0$, Res. $=0.15$

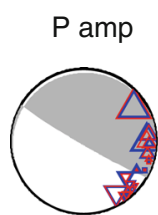

$$
\text { P-axis }
$$

T-axis

Res.
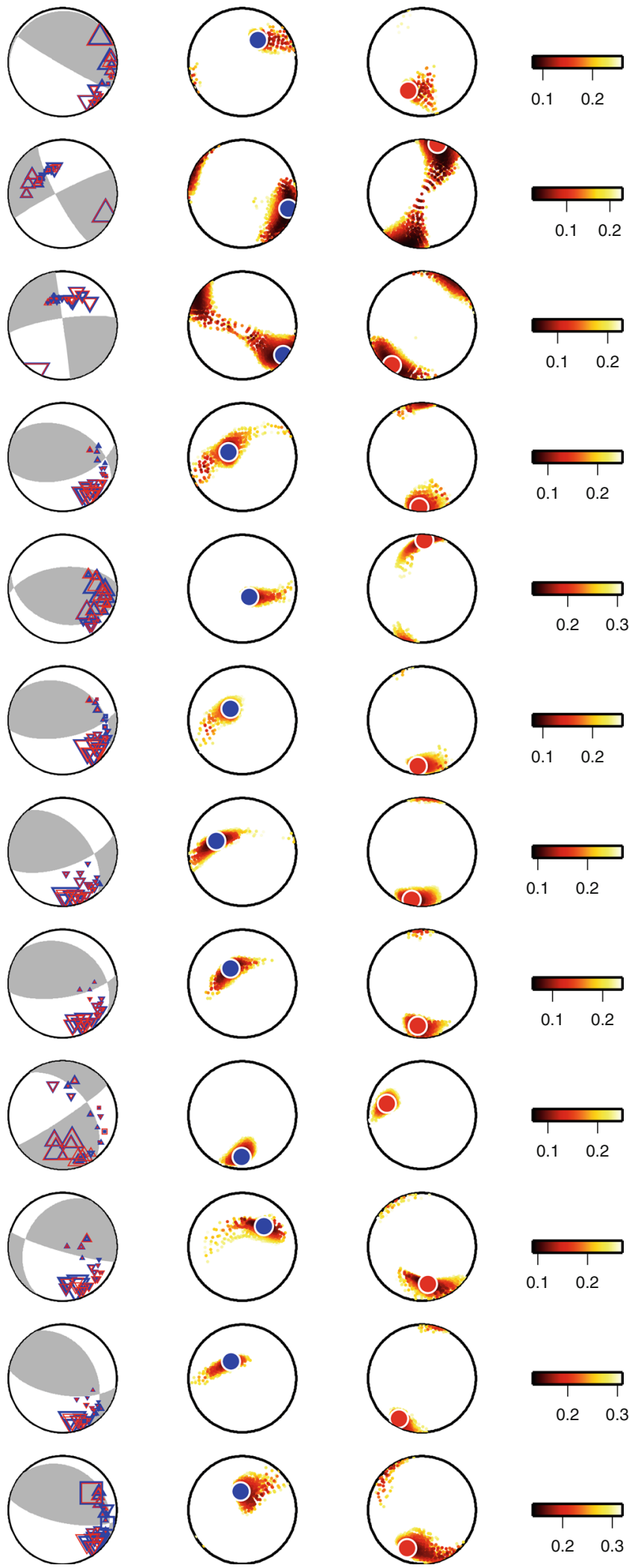
Fig. 8 continued

2012/03/24

$137.1 \mathrm{E}, 33.0 \mathrm{~N}$, dep $34 \mathrm{~km}$

$\mathrm{M}_{\mathrm{L}}=3.4$, Res. $=0.20$

2012/05/29

$137.2 \mathrm{E}, 33.1 \mathrm{~N}$, dep $30 \mathrm{~km}$ $\mathrm{M}_{\mathrm{L}}=3.6$, Res. $=0.42$

2012/05/30

137.3 E, $33.1 \mathrm{~N}$, dep $37 \mathrm{~km}$ $\mathrm{M}_{\mathrm{L}}=3.3$, Res. $=0.36$

$2012 / 06 / 20$

137.3 E, 33.2 N, dep 32 km

$\mathrm{M}_{\mathrm{L}}=3.2$, Res. $=0.09$

2012/07/13

$137.1 \mathrm{E}, 32.8 \mathrm{~N}$, dep $32 \mathrm{~km}$ $\mathrm{M}_{\mathrm{L}}=3.5$, Res. $=0.13$

$2012 / 07 / 14$

$136.9 \mathrm{E}, 32.9 \mathrm{~N}$, dep $29 \mathrm{~km}$ $M_{L}=2.9$, Res. $=0.04$

2012/08/07

$137.0 \mathrm{E}, 32.9 \mathrm{~N}$, dep $27 \mathrm{~km}$ $\mathrm{M}_{\mathrm{L}}=3.1$, Res. $=0.08$

2012/10/19

$137.1 \mathrm{E}, 33.1 \mathrm{~N}$, dep $34 \mathrm{~km}$ $\mathrm{M}_{\mathrm{L}}=4.5$, Res. $=0.06$

2012/11/01

$137.0 \mathrm{E}, 32.9 \mathrm{~N}$, dep $30 \mathrm{~km}$ $\mathrm{M}_{\mathrm{L}}=3.0$, Res. $=0.16$

2012/12/02

137.1 E, 33.0 N, dep $31 \mathrm{~km}$ $\mathrm{M}_{\mathrm{L}}=3.5$, Res. $=0.10$

2012/12/06

$137.0 \mathrm{E}, 33.1 \mathrm{~N}$, dep $31 \mathrm{~km}$ $\mathrm{M}_{\mathrm{L}}=3.2$, Res. $=0.08$

2013/02/04

$136.7 \mathrm{E}, 33.0 \mathrm{~N}$, dep $11 \mathrm{~km}$ $\mathrm{M}_{\mathrm{L}}=3.5$, Res. $=0.11$
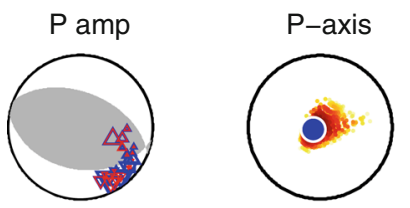

T-axis

Res.
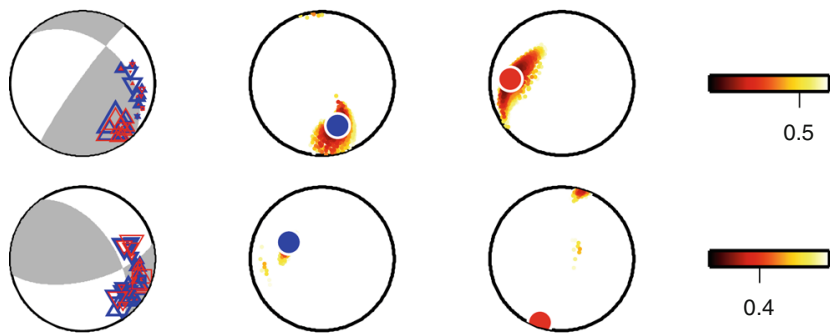

0.4
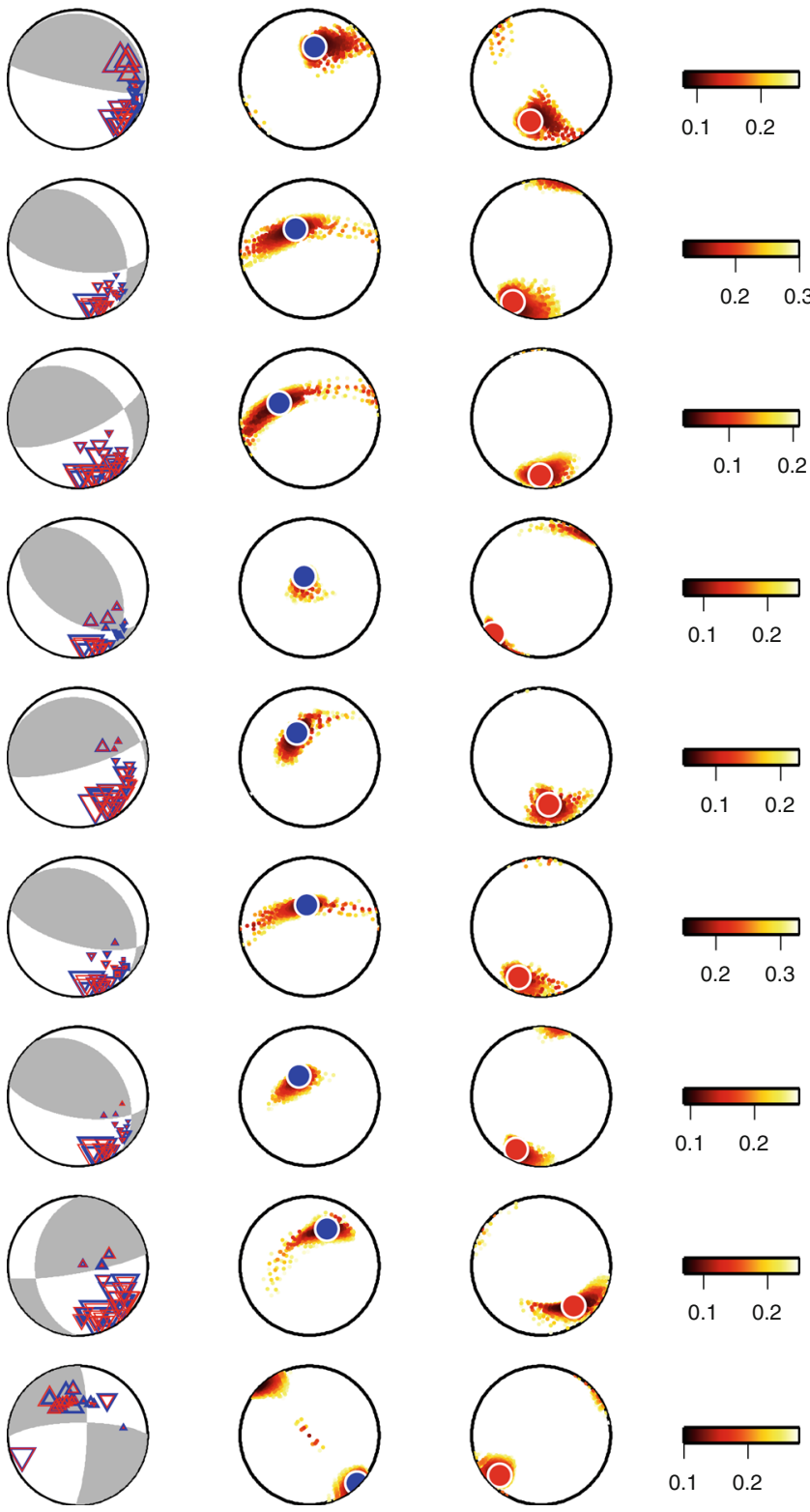
Fig. 9 Comparison of focal mechanisms determined by this study and F-net CMT solution
DONET

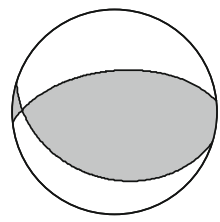

$2011 / 12 / 27$

$137.0 \mathrm{E}, 33.1 \mathrm{~N}, 32 \mathrm{~km}$

$\mathrm{M}_{\mathrm{L}}=4.5$

2012/10/19

$137.1 \mathrm{E}, 33.1 \mathrm{~N}, 34 \mathrm{~km}$

$M_{L}=4.5$
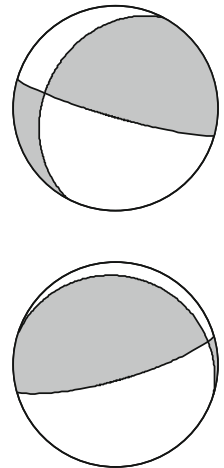

F-net

$2011 / 09 / 14$

$137.2 \mathrm{E}, 33.1 \mathrm{~N}, 23 \mathrm{~km}$

$\mathrm{M}_{\mathrm{w}}=3.4$

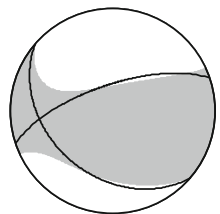

$2011 / 12 / 27$

$136.9 \mathrm{E}, 33.1 \mathrm{~N}, 8 \mathrm{~km}$

$\mathrm{M}_{\mathrm{w}}=3.8$

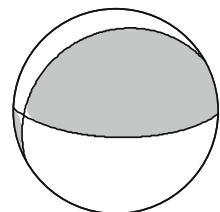

2012/10/19

137.1 E, $33.1 \mathrm{~N}, 14 \mathrm{~km}$

$\mathrm{M}_{\mathrm{w}}=3.7$

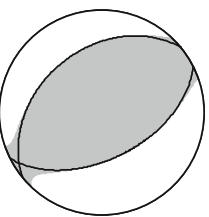

a common phenomenon for earthquakes at plate boundaries. Taking into consideration these observations, the stress field in the PHS plate in our study area is clearly anomalous. One possible explanation is that the stress field has been disturbed by collision at the Izu Peninsula east of our study area (e.g., Obana et al. 2004; Seno 2005; Miyoshi and Ishibashi 2005), but the large difference in orientation of the axes of compressional stress are not well explained by this model. This question requires further investigation.

\section{Conclusions}

DONET ocean-bottom seismic observations have revealed detailed earthquake distributions and tectonic features below the Nankai trough off the Kii Peninsula, which could not have been obtained by onshore observations alone. Our study indicates that most of the seismic activity in the study area represents aftershocks of the 2004 off the Kii Peninsula earthquakes. This seismic activity extends into the uppermost mantle. Focal mechanism solutions suggest that the axis of compressive stress in the PHS plate is oriented $\mathrm{N}-\mathrm{S}$, almost perpendicular to the direction of plate convergence in this region. Our data indicate that intraplate shortening of PHS plate may be occurring below the Nankai trough.

Acknowledgments We used data obtained from the Hi-net and F-net systems operated by NIED and onshore observations obtained by JMA. We thank M. Takaesu and S. Yada for their support with data processing. We also thank Drs. H. Sugioka and Y. Ito for sharing the source parameters of VLF earthquakes. All figures were drawn using Generic Mapping Tools (Wessel and Smith 1998). We greatly appreciate comments from two anonymous reviewers.

Open Access This article is distributed under the terms of the Creative Commons Attribution License which permits any use, distribution, and reproduction in any medium, provided the original author(s) and the source are credited.

\section{Appendix}

Figure 8 shows the stability of the focal mechanism solutions shown in Fig. 5. In Fig. 9, we compare the focal mechanisms obtained by this study and F-net CMT solution. Three events are analyzed by both methods.

\section{References}

Ando M (1975) Source mechanisms and tectonic significance of historical earthquakes along the Nankai trough, Japan. Tectonophysics 27:119-140

Baba T, Cummins PR, Hori T (2005) Compound fault rupture during the 2004 off the Kii Peninsula earthquake (M 7.4) inferred from highly resolved coseismic sea-surface deformation. Earth Planets Space 57:167-172

Boatwright J (1978) Detailed spectral analysis of two small New York State earthquakes. Bull Seismol Soc Am 68:1117-1131

Frohlich (1992) Triangle diagrams: ternary graphs to display similarity and diversity of earthquake focal mechanisms. Phys Earth Planet Inter 75:193-198

Frohlich (2001) Display and quantitative assessment of distributions of earthquake focal mechanisms. Geophys J Int 144:300-308

Hara T (2005) Change of the source mechanism of the main shock of the 2004 off the Kii peninsula earthquakes inferred from long period body wave data. Earth Planets Space 57:179-183

Hirata N, Matsu'ura M (1987) Maximum-likelihood estimation of hypocenter with origin time eliminated using nonlinear inversion technique. Phys Earth Planet Inter 47:50-61

Imanishi K, Kuwahara Y, Haryu Y (2006a) Off-fault aftershocks of the 2005 West Off Fukuoka Prefecture Earthquake: reactivation of a structural boundary? Earth Planets Space 58:81-86 
Imanishi K, Kuwahara Y, Takeda T, Haryu Y (2006b) The seismicity, fault structures, and stress field in the seismic gap adjacent to the 2004 Mid-Niigata earthquake inferred from seismological observations. Earth Planets Space 58:831-841

Imanishi K, Cho I, Kuwahara Y, Hirata N, Panayotopoulos Y (2006c) Focal mechanism solutions of microearthquakes along the central and southern Itoigawa-Shizuoka Tectonic Line active fault system. Annu Rep Act Fault Paleoearthquake Res 6:55-70

Ito Y, Obara K (2006) Dynamic deformation of the accretionary prism excites very low frequency earthquakes. Geophys Res Lett 33:L02311. doi:10.1029/2005GL025270

Ito Y, Matsumoto T, Kimura H, Matsubayashi H, Obara K, Sekiguchi S (2005) Spatial distribution of centroid moment tensor solutions for the 2004 off Kii peninsula earthquakes. Earth Planets Space 57:351-356

Kikuchi M, Nakamura M, Yoshikawa K (2003) Source rupture process of the 1944 Tonankai earthquake and the 1945 Mikawa earthquake derived from low-gain seismograms. Earth Planets Space 55:159-172

Kitajima H, Saffer DM (2012) Elevated pore pressure and anomalously low stress in regions of low frequency earthquakes along the Nankai Trough subduction megathrust. Geophys Res Lett 39:L23301. doi:10.1029/2012GL053793

Kodaira S, Hori T, Ito A, Miura S, Fujie G, Park JO, Baba T, Sakaguchi H, Kaneda Y (2006) A cause of rupture segmentation and synchronization in the Nankai trough revealed by seismic imaging and numerical simulation. J Geophys Res 111:B09301. doi:10.1029/2005JB004030

Kreemer C, Holt WE, Haines AJ (2003) An integrated global model of present-day plate motions and plate boundary deformation. Geophys J Int 154:8-34

Lallemand SE, Malavieille J, Calassou S (1992) Effects of oceanic ridge subduction on accretionary wedges: experimental modeling and marine observations. Tectonics 11:1301-1313

Lallemant S, Chamot-Rooke N, Le Pichon X, Rangin C (1989) Zenisu Ridge: a deep intraoceanic thrust related to subduction, off Southwest Japan. Tectonophysics 160:151-174

Le Pichon, Lallemant S, Tokuyama H, Thoue F, Huchon P, Henry P (1996) Structure and evolution of the backstop in the eastern Nankai Trough area (Japan): implications for the soon-to-come Tokai earthquake. Island Arc 5:440-454

Matsumoto H, Mikada H (2005) Fault geometry of the 2004 off the Kii peninsula earthquake inferred from offshore pressure waveforms. Earth Planets Space 57:161-166

Mazzotti S, Lallemant SJ, Henry P, Le Pichon X, Tokuyama H, Takahashi N (2002) Intraplate shortening and underthrusting of a large basement ridge in the eastern Nankai subduction zone. Mar Geol 187:63-88

Miyoshi T, Ishibashi K (2005) A tectonic interpretation of NW-SE strike-slip faulting during the 2004 off the Kii peninsula earthquakes, Japan: probable tear of the Philippine Sea plate. Earth Planets Space 57:1115-1120

Mochizuki K, Nakahigashi K, Kuwano A, Yamada T, Shinohara M, Sakai S, Kanazawa T, Uehira K, Shimizu H (2010) Seismic characteristics around the fault segment boundary of historical great earthquakes along the Nankai Trough revealed by repeated long-term OBS observations. Geophys Res Lett 37:L09304. doi:10.1029/2010GL042935

Nakamura T, Citak SO, Takahashi N, Kaneda Y, Ohori M, Baba T (2011) A model of three-dimensional seismic structure in the source area of the Tokai-Tonankai-Nankai earthquake. Abstract of Japan Geoscience Union Meeting 2011 SSS035-P32

Nakanishi A, Shiobara H, Hino R, Kodaira S, Kanazawa T, Shimamura H (1998) Detailed subduction structure across the eastern Nankai Trough obtained from ocean bottom seismographic profiles. J Geophys Res 103:27151-27168
Nakanishi A, Takahashi N, Park JO, Miura S, Kodaira S, Kaneda Y, Hirata N, Iwasaki T, Nakamura M (2002a) Crustal structure across the coseismic rupture zone of the 1994 Tonankai earthquake, the central Nankai Trough seismogenic zone. J Geophys Res 107. doi:10.1029/2001JB000424

Nakanishi A, Shiobara H, Hino R et al (2002b) Deep crustal structure of the eastern Nankai Trough and Zenisu Ridge by dense airgunOBS seismic profiling. Mar Geol 187:47-62

Nakanishi A, Kodaira S, Miura S, Ito A, Sato T, Park JO, Kido Y, Kaneda Y (2008) Detailed structural image around splay-fault branching in the Nankai subduction seismogenic zone: results from a high-density ocean bottom seismic survey. J Geophys Res 113:B03105. doi:10.1029/2007JB004974

Nakano M, Nakamura T, Kamiya S, Ohori M, Kaneda Y (2013) Intensive seismic activity around the Nankai trough revealed by DONET ocean-floor seismic observations. Earth Planets Space 65:5-15. doi:10.5047/eps.2012.05.013

Obana K, Kodaira S, Kaneda Y (2004) Microseismicity around rupture area of the 1944 Tonankai earthquake from ocean bottom seismograph observations. Earth Planet Sci Lett 222:561-572. doi:10.1016/j.eps1.2004.02.032

Obana K, Kodaira S, Kaneda Y (2005) Seismicity in the incoming/ subducting Philippine Sea plate off the Kii Peninsula, central Nankai trough. J Geophys Res 110:B11311. doi:10.1029/ 2004JB003487

Obara K, Ito Y (2005) Very low frequency earthquakes excited by the 2004 off the Kii peninsula earthquakes: a dynamic deformation process in the large accretionary prism. Earth Planets Space 57:321-326

Okino K, Kato Y (1995) Geomorphological study on a clastic accretionary prism: the Nankai Trough. Island Arc 4:182-198

Park JO, Gregory FM, Tsuru T, Kodaira S, Kaneda Y (2003) A subducted oceanic ridge influencing the Nankai megathrust earthquake rupture. Earth Planet Sci Lett 217:77-84. doi:10. 1016/S0012-821X(03)00553-3

Saito T, Satake K, Furumura T (2010) Tsunami waveform inversion including dispersive waves: the 2004 earthquake off Kii Peninsula, Japan. J Geophys Res 115:B06303. doi:10.1029/ 2009JB006884

Sakai S, Yamada T, Shinohara M, Hagiwara H, Kanazawa T, Obana K, Kodaira S, Kaneda Y (2005) Urgent aftershock observation of the 2004 off the Kii Peninsula earthquake using ocean bottom seismometers. Earth Planets Space 57:363-368

Satake K, Baba T, Hirata K, Iwasaki S, Kato T, Koshimura S, Takenaka J, Terada Y (2005) Tsunami source of the 2004 off the Kii Peninsula earthquakes inferred from offshore tsunami and coastal tide gauges. Earth Planets Space 57:173-178

Seno T (2005) The September 5, 2004 off the Kii Peninsula earthquakes as a composition of bending and collision. Earth Planets Space 57:327-332

Sugioka H, Okamoto T, Nakamura $T$ et al (2012) Tsunamigenic potential of the shallow subduction plate boundary inferred from slow seismic slip. Nat Geosci 5:414-418. doi:10.1038/NGEO1466

Waldhauser F, Ellsworth WL (2000) A double-difference earthquake location algorithm: method and application to the northern Hayward fault, California. Bull Seismol Soc Am 90:1352-1368

Watanabe $H$ (1971) Determination of earthquake magnitude at regional distance in and near Japan. J Seismol Soc Japan (Zisin) 24:189-200 (in Japanese with English abstract)

Wessel P, Smith WHF (1998) New version of the generic mapping tools released. EOS Trans AGU 76:329

Yagi Y (2004) Source model of the Off Kii-Peninsula earthquake. http://iisee.kenken.go.jp/staff/yagi/eq/Japan20040905/new.html. Accessed 12 December 2012

Yamanaka Y (2004) Source process of the 2004 Off Kii-Peninsula earthquakes determined from teleseismic body waves. 
http://www.eri.u-tokyo.ac.jp/sanchu/Seismo_Note/2004/EIC153. html. Accessed 12 December 2012

Yoshioka S, Matsuoka Y (2013) Interplate coupling along the Nankai Trough, southwest Japan, inferred from inversion analysis of
GPS data: effects of subducting plate geometry and spacing of hypothetical ocean-bottom GPS stations. Tectonophysics 600:165-174. doi:10.1016/j.tecto.2013.01.023 